\title{
Words for Sale: Early Modern Spanish Women's Literary Economy
}

\author{
Nieves Baranda
}

During the early modern period, most Spanish women understood writing as a means of entertainment or self-expression, but a few seventeenth-century female writers built a literary career that gave them prestige as well as financial or economic benefits. These women were proactive in the literary field: they wrote works that were of high commercial interest and could be sold to publishers, composed comedies that were purchased by impresarios to be staged in commercial theatres, received commissions from corporations, and wrote to please patrons who rewarded their work. Besides obtaining direct monetary gains, women writers applied the logic of profit: Luisa Sigea (c. 1522-1560) like other humanists in the first half of the sixteenth century - worked as Latin teacher or secretary for the Portuguese court. Others used literature for utilitarian reasons to promote themselves, their families or their convents. This chapter shows that although there were fewer of them and that they occupied weaker positions, Spanish women writers were active participants of the literary field like their male peers.

I write in accordance with that art which they devised who aspired to the applause of the crowd; for, since the crowd pays for the comedies, it is fitting to talk foolishly to it to satisfy its taste. ${ }^{1}$

Lope de Vega (1562-1635) was the most successful and prolific writer of early modern Spain. He is said to have written over a thousand plays, several thousand poems, and quite a few novels, but more significantly, he can be singled out as one of the first writers to live by his pen. Lope achieved great public recognition, acclaimed as a playwright and as a poet. His life and works were commented upon and hailed and, when he died, he was mourned by a crowd that went out on the streets to honour the writer they considered to be a nature

1 Lope de Vega, Arte Nuevo de hacer comedias [16o9], William T. Brewster tr., New York 1914, 23. This research has been funded by the Spanish Ministry of Economy and Competitiveness, FFI2012-32764 and FFI2015-70548-P BIESES Project. 
monster ("monstruo de la naturaleza"). This success was due to his genius as a writer, but depended also on a cultural system in which his works could be massively disseminated and consumed.

Although a brilliant and sensitive poet, he built his fame as playwright. Permanent theatres initially appeared in Spain, as in other European countries, linked to charitable organizations and by the end of the sixteenth century they were a well-established city feature. Professional troupes appeared and performed actively some time before this period and commercial theater became a new form of entertainment, which attracted paying urban dwellers, contributing to a profitable business. This dramatic tradition dated from the beginning of the sixteenth century and had developed in various forms, as it was capable of adapting to diverse audiences and situations. The increasingly large audiences of permanent theatres played a decisive role in this development as experiments and formulae were tried in order to please them. This was not an easy task, as spectators were heterogeneous due to the attraction of the corrales (theatres) to all members of society. Among a good number of remarkable playwrights (Cervantes being one of them), it was Lope de Vega who devised the essential features of a new genre, the comedia. This genre was to be the basis of Spanish theatre for nearly two hundred years and made Lope the most popular writer of the time. His talent for creating varied plots, mixing situations and characters, as well as his quick response to the demands of audiences and his ability to write plays in a very short period of time ensured his success from the beginning of his career. It also allowed him to make his living from writing by responding to what audiences and theatre companies required. ${ }^{2}$ Furthermore, Lope paid attention to the possibilities offered by the book market and wrote works to please the reading public: novels, lyric and religious poetry and fashionable, miscellaneous books. However, printers were the first to realize plays could be marketable in print when a volume collecting six plays by "Lope de Vega and other playwrights" was published in $1603 .{ }^{3}$ Publishers did not need Lope's permission to print his works as he had lost the property rights when he sold them to the autores ${ }^{4}$ to be staged. His printed plays were organized in partes (parts), volumes that contained between six to twelve plays and were a great

2 A general survey on Spanish theatre in Historia del teatro español, ed. Javier Huerta Calvo, dir., Madrid 2003, I, 611-77. There are plenty of studies on the origin, see for example Jesús Cañas Murillo, "Lope de Vega, Alba de Tormes y la formación de la comedia", Anuario de Lope de Vega, VI (2000), 75-92.

3 Lisboa: Pedro Craesbeck, 16o3; and Madrid: Pedro de Madrigal, 1603.

4 Autor at the time and in a theatrical context referred to the impresario who staged the plays. The Spanish word today means 'author'. 
success. These did not benefit authors, but publishers, who supplied new editions to the market regardless of the playwrights' complaints about the quality of the printed texts and heedless of the fact that the writer received no profit at all. Only in 1617 did Lope gain control of these compilations when he was able to take over the publishing business of his plays, although by then the compilations were already on the ninth volume, and he could not stop printers from producing his works. ${ }^{5}$ Earning his living by writing for a consumer public was not his only literary aim, and Lope also attempted to gain official positions either by pleasing nobles or by flattering the crown. This task relied partly on his fame and visibility as a playwright and partly on the works desired. Patrons expected genealogic plays, epic poems, poetry, or other works on commission. The material value of this production fluctuated based on whether the patronage resulted in a paid permanent post (which Lope never received), in a stipend (if the work was ordered by an aristocrat or an institution, such as the city council or a religious order), or in nothing at all. ${ }^{6}$

Lope de Vega's literary career shows that, by the turn of the seventeenth century, the Spanish literary system offered at least three ways to obtain benefits from work, none of which ruled out the others. Moreover, the professional writer had to compete in all facets in order to be really successful. Firstly, playwrights could sell their plays to theatrical company directors (autores), who often commissioned them, too, and were entitled to alter, reuse and resell them. Consumers decided what the production value was, and so the literary commodity responded to audience tastes to satisfy them. Secondly, although the public was ready to buy printed books, only some genres or topics were considered successful. These included novels and plays which by dint of their ill-matched copyright laws, typically provided benefits only to publishers and rarely to authors. In fact, in both cases, writers' revenues, when dependent on the market and consumers' decisions, were usually obtained by selling the work to a third party that took the risk, either the autor of the play or the publisher, as guarantees on shared benefits were difficult to obtain. The third and most common possibility was to remain loyal to the tradition of patronage,

5 He supervised volumes nine to twenty, and when he died others were ready to be published by his heirs: in all up to twenty-four were printed. Jaime Moll "Tercera parte de las comedias de Lope de Vega Carpio y otros autores", falsificación sevillana", Revista de Archivos, Bibliotecas y Museos, 77 (1974), 619-26; Germán Vega García-Luengos, "La transmisión del teatro en el siglo XVII", in Huerta Calvo ed., Historia del teatro español, t. I., 1289-1320.

6 Elizabeth R. Wright, Pilgrimage to Patronage. Lope de Vega and the Court of Philip III, 15981621, Lewisburg 2001, 134-39. 
which continued for centuries and modeled writers' careers and works dependent on the power field as described in Bourdieu's theories. ${ }^{7}$

\title{
Ana Caro's Professional Career
}

\begin{abstract}
In Seville, on the 2oth of May, 1645. In the dwellings of his lordship Asistente [mayor] met the Committee on the Holy Sacrament feast for this year of 1645 and some autos [religious plays] were considered to be put on stage on the feast day written by Ana Caro. Once seen by the Committee it was decided to order a payment of 300 reales for her work, having made and auto for the feast. ${ }^{8}$
\end{abstract}

Ana Caro, active between 1628 and 1645, understood the logic of literary profit and was paid by the city council and certain aristocrats. Little is known about her life, but there is evidence to show that she took all expected steps to transform her literary talents into a successful career and managed to do so to the same extent as her male writer peers. Without question, she is the most outstanding example of a Spanish professional woman writer of the period and her success can be traced by her works' dedications.

Although there are no records, Caro was supposedly born in Seville, but may also have been native to a village nearby. Her date of birth is unknown, so it is difficult to ascertain how old she was in 1628 , when her first work was published. It is not unreasonable to believe she was born at the turn of the century, or perhaps a few years earlier, as Spanish women writers of this period tended not to publish in their youth.

7 Pierre Bourdieu, Las reglas del arte. Génesis y estructura del campo literario, Barcelona 1995, $318-52$. The methodology has partly been applied to early modern Spain by Donald GilbertSantamaría, Writers on the Market. Consuming Literature in Early Seventeenth-Century Spain, Lewisburg 2005, or Enrique García Santo-Tomás, “Lope, ventrílocuo de Lope: Capital social, capital cultural y estrategia literaria en las Rimas de Tome de Burguillos (1634)", Bulletin of Spanish Studies, 77/ 4 (2000), 287-303, among others.

8 "En la ciudad de Sevilla en 20 días del mes de mayo de 1645 año. En las casas de morada de su señoría Asistente, se juntó la Comisión de la fiesta del Santísimo Sacramento de este presente año de 45. En la cual se vieron unos autos para representar el día de la fiesta, hechos por Ana Caro y los cuales vistos por la Comisión, fue acordado que se le libren 300 reales por el trabajo de aver hecho un auto para esta fiesta", Lola Luna, Ana Caro, una escritora profesional del Siglo de Oro. Vida y obra [Ph.D. Thesis], Universidad de Sevilla, 1992, 21. The auto or auto sacramental was a dramatic genre with an allegorical plot dealing with some aspect of the mystery of the holy Eucharist performed during the Corpus Christi celebrations. For more details see below. 
Her first printed work, Relación en que se da cuenta de las grandísimas fiestas que en el convento de nuestro padre san Francisco de la ciudad de Sevilla se han hecho a los santos mártires del Japón ${ }^{9}$ proves that by 1628 she had already managed to find protectors in the city. From the very beginning she declares the poem to be an object of courtly exchange for a nobleman's favour: "Receive, sir Juan de Elossidieta, this noisy speech [sic] under your shelter ... you may well say that has been a ruse to rely on you, that is expensive [caro] for you as I have wanted something worthless to nearly match the highest grandeur." ${ }^{10}$ This first printed work meets the requirements of an eulogistic genre exchanging money for praise. The poet's obligation is to present an idealised image of the patron and the city authorities in several respects: religion, wealth, generosity, courage and loyalty. Expensive festivities organised by public institutions were crucial in transmitting ideology, and maintaining social structures and cohesion. During celebrations, social groups displayed their power, authority and prestige through their appearance and the place they occupied, a demonstration that served to keep hierarchal and corporate order. Celebrations were made for showing adherence to public religious or political values and commitment to the Catholic Church and the Crown. All of them participated, but a prominent role was given to the elites, to legitimise their status before the commoners and to exhibit their position and aspirations to other groups or town institutions. However, public events were limited in space and time and other secondary forms of dissemination were needed to increase and enhance their effectiveness. Printed chronicles, either booklets or large books including speeches, sermons, poetry and so on, were used to reach a wider audience and extend the exhibitionism of public events. The image of the city, its wealth, the courage of the elites (the most prominent groups or noblemen) and their allegiance to the Crown and Kingdom were disseminated as an ideological agenda amplified and broadened to a national or international scale; a local event turned into a means of promotion.11

$9 \quad$ Report on the huge Feasts our father Saint Francis Convent of Seville has celebrated for the Martyrs in Japan. (Sevilla 1628); edition by Francisco López Estrada, "La relación de las fiestas por los mártires del Japón, de doña Ana Caro de Mallén (Sevilla), 1628” in Librohomenaje a Antonio Pérez Gómez, Cieza 1978, II, 161.

10 "Recibid señor Juan de Elossidieta/este ruido discurso en vuestro amparo/.../Podéis decir muy bien que ha sido treta/el valerme de vos, que os cuesta Caro,/pues he querido lo que nada vale/que a la mayor grandeza casi iguale", Luna, Ana Caro, 319. The writer makes a pun using her family name, Caro, which means expensive.

11 José Antonio Maravall, La cultura del barroco. Análisis de una estructura histórica, Barcelona 1981, 487-98; Christine Kaplisch-Zuber, "Rituals publics et pouvoir d'état" in Culture et ideologie dans la genese de l'état moderne, Rome 1985, 136-53; Pedro Gómez García, "Hipótesis sobre la estructura y función de las fiestas", in La fiesta, la ceremonia, el rito, 
Relaciones or short chronicles were used to represent parties and their positions in the politics of the Kingdom, but they also played an important role on a local level as accounts, which helped form a collective memory for the local community. Various social agents were interested in controlling narratives to ensure they worked in their own interest: something that could be achieved by commissioning a relación, which exalted adequate values and people. Caro's first printed work is one such short chronicle, and depicts an idealised image of a celebration. It is not a freely inspired poem, but a commissioned text that must obey certain rules of rhetoric and comply with a maximum length for the printed format. ${ }^{12}$ The poem is written in hendecasyllable verses laid out in 48 stanzas in octava rima, and uses a learned style to dignify the topic adorned by a lavish rhetoric with plenty of adjectives. Each subject's importance is commensurate with its length: two stanzas for the dedication, four on the Franciscan martyrs in Japan and 41 describing the celebrations. In this long section, church and city adornments are depicted, some famous preachers' and noblemen's names are mentioned, but narration focuses on the deeds of a group of Basque gentlemen. At least twelve stanzas, including the last one, are devoted to this group. They talk about their fame as glorious heroes for which they are granted prominent positions. The work is dedicated to an unknown Don Juan de Elossidieta, whose surname suggests he was of Basque origin. Considering he is not directly mentioned in the celebrations, but the "noblemen from Guipúzcoa and Biscay"13 are praised, it can be guessed that the payment hinted by Caro's words was meant to please the national group Elossidieta belonged to, as Caro's poem flatters Basques for their military condition. People from the Basque region were an important group in seventeenth-century Seville. They traded in gold and silver from the American colonies and were businessmen and bankers closely linked to institutional powers, where they often held office. Receiving such commission proves Caro was a respected writer with connections to the city elites. Otherwise - in a city where many celebrated writers already lived, ready to take up a likely well-paid assignment - she would not have been entrusted with the task.

Granada 1999, 51-62. An excellent overview in Teresa Ferrer Valls, "La fiesta en el Siglo de Oro: en los márgenes de la ilusión teatral", Teatro y fiesta del Siglo de Oro en tierras europeas de los Austrias, Madrid 2003, 27-37.

12 The Relación is 16 pages long in an octavo edition. See on women writers' Relaciones and pamphlets M a Carmen Marín Pina, "Public Poetry", in The Routledge Companion to Early Modern Spanish Women Writers, London/ New York 2017, 205-18.

13 "nobles de Guipúscua y de Vizcaya", Francisco López Estrada, "Costumbres sevillanas: el poema sobre la Fiesta y Octava celebradas con motivo de los sucesos de Flandes en la Iglesia de San Miguel (1635), por Ana Caro de Mallén", Archivo Hispalense, LXvi/203 (1983), 165, line 193 . 
Caro's search for patrons seems to trace an ascending path when evidence taken from the dedications in her printed works is followed. Leaving aside the poem published in 1633 that extols a small raid for loot in enemy territory, ${ }^{14}$ another, dated 1635 , is dedicated to the Countess of Salvatierra. In 1637, each of the three parts of a short work is allocated to different dedicatees: Agustina Spinola, wife of a royal banker, the Count-Duke of Olivares, King Philip IV's Prime Minister and favourite, and the city of Madrid. The Grandiosa Vitoria que alcançó de los moros de Tetuán (Grand Victory Over the Moors of Tetouan) is dedicated to its hero, Jorge de Mendoça y Piçaña, the Portuguese General and Governor of Ceuta who most probably ordered the relación to draw attention to and magnify his evidently small victory on the battlefield. The Countess of Salvatierra, Leonor de Luna Enríquez, was married to the Sevillian mayor who had organised celebrations described in the Relación de la grandiosa fiesta y octava que en la iglesia parroquial de el glorioso san Miguel de la ciudad de Sevilla hizo don García Sarmiento de Sotomayor, Conde de Salvatierra. ${ }^{15}$ The celebration's object was an event that occurred during the Thirty Years War, which was thoroughly disseminated by sermons and printed propaganda in order to ideologically stir up the population. As above, Ana Caro's long poem narrates the episode and denigrates the heretics' wickedness in only 130 verses out of 873 (approximately 15 per cent). In the two other parts, the incident is mentioned mostly amongst descriptions of festivities, the Church, decorations, processions and fireworks in artificial and exalting vocabulary. Few names are mentioned in the poem: the Counts' of Salvatierra and the preachers'. Seville nobility is referred to as a group (line 705), but lines 202 through 221 deal with the Counts. Strategically placed at the end, more than 100 verses praise the virtues of the asistente comparing him to the archangel St. Michael: one in heaven and the other on Earth. It is hard to establish if the relación was commissioned first or if Caro wrote it for a coterie and published it to seek a reward that would end in payment and a printed broadsheet with the text. Ana Caro's strategy to approach the city's most powerful man searching for a profitable patronage is clear. ${ }^{16}$ The four preliminary poems in the booklet praise Caro as

14 Edition by Francisco López Estrada, "La frontera allende el mar: el romance por la victoria de Tetuán (1633) de Ana Caro de Mallén” in Homenaje a José Manuel Blecua, ofrecido por sus discípulos, colegas y amigos. Madrid 1983, 337-46.

15 Chronicle of the grand celebration and octave that in the parish church of the glorious Saint Michael of Seville was done by García Sarmiento de Sotomayor, Count of Salvatierra, Seville 1635 .

16 Carlos M. Gutiérrez, La espada, el rayo y la pluma. Quevedo y los campos literario y de poder, West Lafayette, Ind. 2005, 157, makes a difference between commissioned works and the others: "the others usually try to attune to what is believed to be a cultural expectation 
an author, festivities narrator and "Seville muse", and were useful for that purpose as it is implied that, just as the Count of Salvatierra occupies the celebrations summit, she as a poet matches his position in the literary field. Poets used eulogic texts to fashion their own authorial image in order to obtain social recognition, ${ }^{17}$ especially as patrons desired association with prestigious writers, who showed their worth by using a learned rhetoric (as in Caro's poem) and had achieved recognition among their peers. This relación might have been a means to draw the attention of the Count of Salvatierra, who being appointed asistente (mayor) of the city, had arrived in Seville the year before.

Ana Caro was not prominent in the urban literary circles at that time. The eulogistic preliminary poems' authors in the 1635 booklet were of little or no consequence in the Seville Parnassus at the time, meaning she did not belong to the city's main coteries yet. These links developed around those years. The Seville poet and playwright, Luis Vélez de Guevara, high servant to King Philip IV, describes a literary academy held about 1637 in the house of the Count of Salvatierra (mayor between 1634 and 1641), where Ana Caro, "Seville tenth muse", read a poem in honour of Lope de Vega. ${ }^{18}$ Other prominent writers mention her in those years: in approximately 1637, María de Zayas asked her for a poem to be included in the paratexts of her Novelas amorosas y ejemplares (Amorous and Exemplary Novels) edition; Alfonso de Batres mentions Caro as participating in the Academy of Buen Retiro in Madrid in 1638; and in 1644, Alonso de Castillo Solórzano depicts her accompanying María de Zayas in the same city. ${ }^{19}$ Citations show that her value in the literary society increased and

horizon in the power field. That is to say some works adopt certain twist more because of the active principle of cultural agents, good judges of the possibilities, than because of requirements (which existed)" ("lo que suele pretender el resto de las obras es concordar con lo que se percibe como un horizonte de expectativas culturales del campo del poder. Es decir, que algunas obras adquieren un sesgo determinado más por principio activo de los agentes culturales, bien conocedores del espacio de posibilidades, que por imposiciones (que las había)"). Ana Caro, lacking direct commissions, would be in the second group looking for immediate profit if no other options of paid engagement were open.

$\mathrm{M}^{\mathrm{a}}$ Grazia Profetti, "Poder y estrategias editoriales de Lope de Vega", in Représentation, écriture et povoir en Espagne a l'epoque de Philippe III (1598-1621), eds M.G. Profeti and A. Redondo, Firenze 1999, 87-105.

18 El diablo cojuelo [1641] eds Ángel R. Fernández and Ignacio Arellano, Madrid 1988, 211. If the internal chronology of the story is considered to be right, the described literary meeting had to be held in 1637 or later, because the character recites a poem written for a celebration in the court that year, see Inmaculada Osuna, "Literary Academies and Poetic Tournaments", in The Routledge Research Companion to Early Modern Spanish Women Writers, eds N. Baranda and A.J. Cruz, Oxon/ New York 2018, 156.

19 "[Zayas] is accompanied by Dona Ana Caro Mallén, lady from our Seville, to whom no less praise is due, because with her sweet and thoughtful verses suspends and delights all who 
that she improved her position. Well-known writers living in Madrid, and particularly the court - the place where everyone looked for fame - were aware of her literary production, which meant Caro's fame had traversed the limited Andalusian border to touch the sought-after Parnassus of her time.

These mentions went together with a rise in her patrons' rank, as she reached the Count-Duke of Olivares, King Philip's IV favourite. Caro arrived in Madrid early in 1637 and spent part of the year there. The Count-Duke of Olivares had resided in Seville between 1607 and 1615, where he was a patron of writers, and Caro was likely connected to the court circle that led her to the heart of power. When called to the royal court, some patronised writers followed the Count-Duke; for example, the poet, Francisco de Rioja, his secretary and librarian, Francisco de Calatayud, his official biographer and Juan Antonio de Vera, Count of La Roca, ambassador and author of his panegyric. ${ }^{20}$ Caro's connections to this group may explain why she moved to Madrid and account for her success in publishing the Contexto de las reales fiestas que se hicieron en el palacio del Buen Retiro. A la coronación del rey de Romanos y entrada en Madrid de la señora princesa de Cariñán, en tres discursos. ${ }^{21}$ Making the most of the possibilities of patronage, the book has three parts and three different dedications: the first to Agustina Espinola, banker Carlos Strata's wife, ${ }^{22}$ the second to the Count-Duke of Olivares and the third to the city of Madrid. The

hear and read them, as proved by the ones she wrote to the last carnival festivities held in the Buen Retiro ... She depicts everything with as much ornament and decorum as such a great celebration deserved. ..." (“Acompáñale en Madrid doña Ana Caro de Mallén, dama de nuestra Sevilla, a quien se deben no menores alabanzas, pues con sus dulces y bien pensados versos suspende y deleita a quien los oye y lee; esto dirán bien los que ha escrito a toda la fiesta que estas carnestolendas se hizo en el Buen Retiro ... pues trata della con tanta gala y decoro como mereció tan gran fiesta. ..."), Alonso de Castillo Solórzano, La garduña de Sevilla y anzuelo de las bolsas, ed. Federico Ruiz Morcuende, Madrid 1972, 67. On Ana Caro and the social literary world, see Alicia R. Zuese, "Ana Caro and the Literary Academies of Seventeenth-Century Spain", in Women's Literacy in Early Modern Spain and the New World, eds Anne J. Cruz and Rosilie Hernández, Hampshire/Burlington 2011, 191-208.

$20 \quad$ Poder y saber. Bibliotecas y bibliofilia en la época del conde-duque de Olivares, Madrid 2011. John H. Elliot, The Count-Duke of Olivares. The Statesman in an Age of Decline, New Haven 1986, 21-30; José Luis Colomer, "El conde de la Roca y el marqués Virgilio Malvezzi. Dos diplomáticos panegiristas del Conde Duque de Olivares", in Por discreto y por amigo. Mélanges offerts à Jean Canavaggio, eds Christophe Couderec et Benoit Pellistrandi, Madrid 2005, 513-34; and Gutiérrez, La espada, 150-56.

21 Chronicle of the royal festivities done in the Buen Retiro Palace. To the coronation of the Romans King and the entrance of her ladyship the Princess of Carignan in Madrid, in three discourses, Madrid 1637, ed. Lola Luna in Bieses: http://www.bieses.net/ana-caro-mallencontexto-de-las-reales-fiestas/

22 According to Elliot, The Count-Duke, 503, he was "one of the most flamboyant of the Genoese bankers" and had lent the Spanish Crown the fabulous sum of 2,150,00o escudos in 
preface to the reader and the dedication to the Count-Duke suggest that Caro took the initiative to compose the work and circulate the manuscript until she was asked to have it printed. Manuscript and printed poetry circulation were concurrent channels, and success with handwritten copies could lead to the press, although some changes for the wider reading public could be necessary for texts with a strong political subject. Caro states at the beginning:

it is badly reasoned because it was written not to be published and with a different matter, as can be realised by my reluctance to put it to print, I do it now changing the beginning, so it will be less common ... [emphasis added] ${ }^{23}$

Only one version of the work remains, so it is impossible to know how it was changed, but reading the other dedications carefully, it seems that it might have been more than the beginning. When addressing the Count-Duke, Caro states the work was written for Seville ("The Relación de las fiestas reales del Buen Retiro I wrote to Seville and your excellency saw, I was asked to put to print ..."), ${ }^{24}$ but that it is not in the text. The third part is also dedicated to the city of Madrid and the text says in an apologetic tone: "and so, although late, I offer to your Lordship this little part of my great love [emphasis added, $\mathrm{NB}]$ ". 25 These differences suggest that after circulating the manuscripts she was asked to prepare a new version to be printed. She was to leave the relaciones dedicated to the banker's wife and the minister untouched, and had to add a third one dedicated to Madrid, perhaps to replace the one she had written for Seville, hence the excuse of having done it late. Documents show the city lavishly paid 100 ducats to the author. ${ }^{26}$ Each city council nobleman is mentioned

1635. His wife, Agustina Spinola, belonged to another of those wealthy Genoese families so Caro was aiming at the acme of the social pyramid.

23 "lo mal razonado de él es haberse hecho sin intención de publicarlo y con diferente asunto, como se conocerá en la remisión que he tenido para darle a la estampa, hágolo ya, mudándole el principio, causa de que vaya menos corriente...", Caro, Contexto, n.p., discourse I.

24 "La Relación de las fiestas reales del Buen Retiro que escribí a Sevilla y vuestra excelencia vio, me han pedido que imprima...", Caro, Contexto, n.p., discourse II.

25 "y así, aunque tarde, ofrezco a vuestra señoría esta pequeña parte de mi mucha afición", Caro, Contexto, n.p., discourse inI.

26 "Payment letter to dona Ana Caro de Mallén, 100 ducats for the Relación de las fiestas. Madrid, 3oth, August, 1638. Before Pedro de Castro" "Carta de pago de Doña Ana Caro de Mallén, de 100 ducados por la Relación de las fiestas. Madrid, 30 de Agosto de 1638. Ante Pedro de Castro") (Cristóbal Pérez Pastor, Noticias y documentos relativos a la historia y literatura españolas, Madrid 1910, I, 97). To get an idea of how much it was, the same amount was paid to Velázquez in 1629 for the picture The Triumph of Bacchus, see José Gudiol, Velázquez, 1599-1660: historia de su vida, catálogo de su obra, estudio de la evolución de su técnica, Barcelona 1973, 87. 
by name and surname and their contribution to the celebrations depicted with flattering images, which correspond to the expected eulogistic tone of these poems. ${ }^{27}$ It is more revealing that every preface includes the word generosidad (generosity) an ambiguous term meaning mostly 'from high lineage', but also 'lavish' in modern Spanish: "the noble generosity of Carlos Strata"; the CountDuke is a "generous shelter"; and she pleads the city "being so generous" to receive her present. ${ }^{28}$ Courtesy and praise barely hide the author's anxiety for the economic benefit of a piece that was made for exactly that: to meet the expectations of a select few, who paid a high price to feel flattered and be portrayed in ennobling lights. It was one of the most common modes of exchange between writers and powerful patrons and Ana Caro knew well how to manage this. Nevertheless, there were other possibilities and she did not ignore emerging economic forces that sustained a market not yet independent or strong enough to free the writer of servitude from the ruling class, but already interesting enough to draw her attention and dependency. Addressing the public, she boldly states in the preface: "I beg you to censor it as yours and buy it as alien, as this way if you are not happy I shall be paid". ${ }^{29}$ The Contexto de las reales fiestas (Account of the Royal Festivities) is not only the biggest step in Caro's progression under patronage, as she managed to touch with her fingertips the Kingdom's acme of political and financial power, but unlike her previous relaciones, this one proves her awareness of the commercial value of writing and thus her work caters to two possible means of literary profit.

Caro wrote plays too, possibly the most marketable genre of the time, and succeeded in making profit in more than one respect. In the document previously quoted, a commission of Seville's city council ordered her to be paid for having written a play for the Corpus Christi festivities which were among the most

27 The dedication to Agustina Spínola, as the previous one to the Countess of Salvatierra, is in fact to her husband. Texts mention wives, but refer to their husbands with even longer praise. Including the spouse was not an obligation in dedications to women, see Nieves Baranda, "Women's Reading Habits: Book Dedications to Female Patrons in Early Modern Spain”, in Women's Literacy, eds Cruz and Hernandez, 19-39.

28 The semantic field of generous ('lavish') is especially significant in the dedication to Agustina Spinola, using expressions as clear as "her more than liberal spirit" ("el más que liberal ánimo suyo") or even in the hardly veiled statement: "I assure my wit rich gains" ("aseguro a mi ingenio ricas medras"), Caro, Contexto, n.p., discourse I.

29 "suplícote le censures como tuyo y le compres como ajeno, que con esto, si tú no contento, yo quedaré pagada", Caro, Contexto, n.p., discourse I. Printing and the market were valued differently depending on the literary system. On the Spanish literary market, see GilbertSantamaría, Writers on the Market, 13-20. According to Kim Walker, Women Writers of the English Renaissance, New York 1996, 146, in England women avoided writing openly for a financial gain as it could be seen as prostitution (see also the introduction to this volume). 
important of the religious calendar because they extolled the sacrament of the Eucharist that had become a hallmark of Catholic identity after Trent. These festivities took place in the spring and cities, according to their wealth, organised all kinds of celebrations, including street adornment, music, dances, fireworks, religious processions and the staging of public plays. Religious theatre was one of the highlights of the program. Unlike the plays staged in corrales (public theatres for a paying audience), these Corpus Christi allegorical representations were staged on carts in selected places of the municipality because the city council hired the companies and could even commission the plays. Between 1641 and 1645, the city of Seville paid Ana Caro for three different autos that were staged during the Corpus Christi feast. ${ }^{30}$ These payments illustrate the commercial nature of her work, but also her fame. Literary renown was essential to get an auto on stage, but in order to be well paid, connections with local authorities were necessary, too. There remains no evidence of municipal payments to Caro before her journey to Madrid, which may be due to archival losses, but could also suggest that her visit to the court there was the basis of her increased prestige upon her return to Seville. This hypothesis cannot be proved, but would be consistent with a growing career where decisions are made considering profit. The Corpus Christi auto payment offered her an income to reinforce her economic independence and literary value so it can be considered one more step forward in her professional progress.

Ana Caro did not just write autos, but commercial plays for public corrales. ${ }^{31}$ Although she may have written many more works, only two comedies remain: El conde Partinuplés (The Count Partonopeus) and Valor, agravio y mujer (Courage, Affront, and Woman). There are manuscript copies and prints of these plays, so likely they were successful, sold to an autor (theater manager) and staged. ${ }^{32}$ Commercial theatre in the late sixteenth century, since the consolidation of public success developed on a thriving market based on printing plays, as previously mentioned, but playrwrights did not receive the benefits of this printed trade because they lost all rights in the work when sold for being performed. Impresarios obtained an additional benefit by selling the script to

30 José Sánchez Arjona, Noticias referentes a los anales del teatro en Sevilla, desde Lope de Rueda hasta fines del siglo XVII, Sevilla 1898, 341-59. She was paid 300 reales for each of them. The same amount is paid for a month's work to the manager of a weapons factory in Tolosa (Navarra), Ignacio M. Carrión Arregui, "El trabajo en una manufactura real del siglo XVII: los armeros de la Armería de Tolosa”, Vasconia, 30 (2000), 79. I am indebted to Teresa Ferrer Valls for the questions she answered on this writer.

31 Corral de comedias, literally a "theatrical courtyard", was the open-air enclosed rectangular courtyard typical of a block of houses used for staging dramas. They began as occasional sites, but the structure was maintained in permanent theatres. Valor, agravio y mujer, ed. Lola Luna, Madrid 1993; and El conde Partinuplés, Kassel 1993. 
printers who were interested in publishing successful works, so a printed play is usually the result of several sale contracts; the first of them organised by the playwright. ${ }^{33}$ Caro's El conde Partinuplés is included in Laurel de comedias, cuarta parte, a compilation of several plays (1653) and Valor, agravio y mujer was published twice as a suelta (a booklet or an offprint), which functioned to disseminate theatre by producing thousands of copies during the seventeenth and eighteenth centuries.

\section{María de Zayas: Novels to be Purchased}

Nowadays shines and stands out with joyous laurels Dona Maria de Zayas y Sotomayor's wit, who has rightfully earned the title of Sybil of Madrid, acquired by her admirable verses for her fortunate wit and great prudence, having given to print a book of ten novels that are ten wonders for those who write this genre ... She is accompanied by Dona Ana Caro Mallén, lady from our Seville, to whom no less praise is due ..." ${ }^{34}$

On her trip to Madrid in 1637, Caro met María de Zayas, the most famous female writer in the court at the time. ${ }^{35}$ Unfortunately, little can be said of her life and literary relations, aside from citations and conclusions derived from her works. Nevertheless, it is clear that she deliberately sought to be visible in the literary world of Madrid, and put in every effort to publish and reach revenues. María de Zayas began to be noted in Madrid's coteries in the twenties. In 1621, 1622, 1624 and 1626, some of her poems were published in the preliminary parts of other authors' works published in Madrid and, in 1629, in

33 Historia del teatro español, ed. Huerta Calvo, I, 1289-93 and 1305-10. Women were quite active in theatre, see Teresa Ferrer, "La mujer sobre el tablado en el siglo XVII: de actriz a autora", in Damas en el tablado. Actas de las XXXIJornadas Internacionales de teatro clásico de Almagro (1-3 de julio de 2008), Almagro 2009, 83-100, an activity that has been compared to England; Iván Cañadas, Public Theater in Golden Age Madrid and Tudor-Stuart London: Class, Gender and Festive Community, Aldershot/Burlington 2005.

34 "en estos tiempos luce y campea con felices lauros el ingenio de doña María de Zayas y Sotomayor, que con justo título ha merecido el nombre de Sibila de Madrid, adquirido por sus admirables versos, por su felice ingenio y gran prudencia, habiendo sacado de la estampa un libro de diez novelas que son diez asombros para los que escriben deste género ...[...] Acompáñale en Madrid doña Ana Caro de Mallén, dama de nuestra Sevilla, a quien se deben no menores alabanzas ...", Castillo Solórzano, La garduña, 66.

35 On María de Zayas and her relationship to Ana Caro, see Mercedes Maroto Camino, "Maria de Zayas and Ana Caro: The Space of Woman's Solidarity in the Spanish Golden Age", Hispanic Review, 67 (1999), 1-16. 
the Laurel de Apolo (Laurel of Apollo) Lope de Vega considered her part of the literary coteries. Lope's work is a Parnassus where he names and appraises many contemporary writers who had some name: "immortal Maria de Zayas [...] because her vividly clear wit,/is so unique and rare/she alone could give fame to the city of Madrid". ${ }^{36}$ Citations prove her friends were some of Madrid's best-known writers, involved in active literary coteries attentive to the commercial advantages of publishing. This group included poets, playwrights and novelists interested in marketing literature. For instance, Juan Pérez de Montalbán, son of a publisher, the Portuguese Miguel Botelho de Carvalho, who published in Rouen Violante do Céu's Rimas (1646) and of course, Lope de Vega. ${ }^{37}$ Commendatory poems of some of them mention María de Zayas' first published collection of novels, Novelas amorosas y ejemplares, reinforcing that she belonged to a particular literary group and had power within it. ${ }^{38}$ The focus of these commendatory poems on the writer is significant, and there are several voices involved. Her friends praise her as laureated poet, and Ana Caro, perhaps because of a gender consciousness, considers her a glory for Spain and places her as descending from illustrious classical writers, such as Sappho or Pola Argentaria. The prose preface by a Desapasionado provides evidence. Choosing "dispassionate" as a nickname stresses it is an objective voice, ${ }^{39}$ but the text presents inordinate praise: Zayas' wit as a woman excels all the rest, her fame has been reckoned and acclaimed by the court, which implies she is commended by the best. Moreover, her works combine wit and morality, two attractive features with a socially educational message. This advertising aims to convince the reader that the book must be owned, not only read, but it must be paid for: "and not borrowed but purchased with your own money; no matter what it costs, it will be well spent money".40

Zaya's preface to the reader has been repeatedly studied for it is dependent on the Querelle des femmes tradition, defending women's right to study and

36 Félix Lope de Vega Carpio, Laurel de Apolo, ed. Christian Giaffreda, Firenze 2002, 258.

37 María Dolores Martos Pérez, "De musas a poetas: escritoras y enunciación canonizadora en la obra de Lope de Vega", Arte nuevo 4 (2017), 787-847.

38 Zaragoza 1637. Commendatory poems by Alonso de Castillo Solórzano, María Caro de Mallén, Juan Pérez de Montalbán, Francisco de Aguirre Vaca. The edition was published in Zaragoza because printing novels or plays was forbidden in Castile between 1625 and 1634 so some writers travelled to Aragon to publish their works as there were different laws. Nonetheless, Zayas carried the poems with her manuscript work as writers were from Madrid.

39 Some translations use "objective reader".

40 "no pidiéndolo prestado, sino costándote tu dinero; que aunque fuese mucho le darás por bien empleado", María de Zayas, The Enchantments of Love: Amorous and Exemplary Novels, tr. H. Patsy Boyer, Berkeley 199o, http://ark.cdlib.org/ark:/1303o/ft638nb3jd/ 
write, but there are also some striking statements about the commercial value of writing. ${ }^{41}$ Firstly, the importance given to the printing-press as a way of measuring a book's quality: "until the writings enjoy the lead, letters have no true value and firmness". ${ }^{2}$ Here Zayas implicitly states that the value of literary work does not reside in the judgments of writers and patrons, but on the decision of the market, as only through extensive dissemination to the public can quality be tested. Moreover, it does not depend on positive reviews, but on something as material as money: the revenues obtained in exchange for the literary product prove its worth. The process by which a writer reaches that point is synthetically described thus:

From this inclination [to books] came information, and from the information good taste, and from this the writing of poetry, and then the writing of these novellas, perhaps because they seemed easier or more interesting to write. Books that aren't erudite can be good if they have a good subject, while many works filled with subtlety are offered for sale but never bought because the subject is unimportant or not pleasing. ${ }^{43}$

Zayas did not care that her novels were criticised as too easy or too popular, because as she points out there are many highbrow books for sale, which remain ignored. Her aim is clearly commercial, writing for selling, and she agrees with Lope de Vega: "for, since the crowd pays for the comedies, it is fitting to talk foolishly to them to satisfy their taste". Zayas seems to understand that being an author is having one's name printed on the book's title page, and she shares the groundbreaking ideas of her coterie, introduced by Lope de Vega and accepted by those who understand that pleasing readers ("easier or more interesting") triggers a satisfying exchange of literary product for money ${ }^{44}$ It is not possible to infer that Zayas, being a woman, was in search of a market,

41 Many critical studies could be mentioned but Yolanda Gamboa, "María de Zayas, or Memory Chains and the Education of a Learned Woman", in Women's Literacy, eds Cruz and Hernández, 209-24, sums up most of them and she adopts a point of view useful for our arguments.

42 "hasta que los escritos se gozan de las letras de plomo no tienen valor cierto ni firmeza", Zayas, The Enchantments, cit. ed.

43 "Desta inclinación nació la noticia, de la noticia el buen gusto, y de todo hacer versos hasta escribir estas novelas o por ser asunto más fácil o más apetitoso, que muchos libros sin erudición suelen parecer bien en fe del sujeto y otros llenos de sutileza se venden, pero no se compran, porque la materia no es importante o es desabrida", Zayas, The Enchantments, cit. ed.

44 Isabel Enciso Alonso-Muñumer, "Nobleza y mecenazgo en la época de Cervantes", Anales Cervantinos, 40 (2008), 47-61. 
although it might have been so, considering that women writers had limited expectations in a patronage system that had no jobs for them. In a competitive environment that excluded them from certain potential benefits because of their gender, they may have turned this into an asset, since a woman writer could arouse readers' curiosity precisely for that same reason. The feminine identity is underlined in every woman writer's paratext when the book is meant to compete in the market. ${ }^{45}$ Although the trope was usually meant to fashion a humble authorial position, in these cases it aimed to add interest to the work and invite the reader to behave courteously, i.e. more favourably, towards the female author.

María de Zayas' Novelas ejemplares were a great success. There were five or six different editions between 1637 and 1646, a compelling reason to write a sequel. The real economic benefit she obtained is difficult to determine. The work does not bear privilegio (privilege), which was the exclusive right to print a book for a certain period, so others could take advantage and reprint it without the author's permission. In her second collection of short stories or novelas, she mentions her success and boasts that the work "has enjoyed three prints, two natural and one stolen" ("ha gozado de tres impresiones, dos naturales y una hurtada"), ${ }^{46}$ suggesting that two of those editions had her permission and economic control and the third was made by an unscrupulous printer, underlining again that the work was very profitable. The success and fame it brought opened the way to publishing and most probably pushed her to write a second collection of ten novels. It is now known as Desengaños amorosos (Deceits of Love), although it was originally published as Segunda parte del sarao y entretenimiento honesto (Second Part of the Soiree and Honest Entertainment, Zaragoza, 1647) establishing a clear association with the Novelas amorosas to take advantage of the previous book's fame, according to market logic. Although it was a success, it is unclear if Zayas benefited from this second book, ${ }^{47}$ but it is

45 For instance: Ana de Leyva, Ana de Castro or Ana Caro, apart from María de Zaya - see BIESES database for information on their works. Esther Villegas explores how some women used gender as a visibility mark for literary purposes: "Transatlantic interactions: seventeenth century women authors and Literary self-consciousness" in Identity, Nation, Discourse. Latin American Women Writers and Artists, ed. Claire Taylor, Newcastle upon Tayne 2009, 104-21.

46 María de Zayas, Desengaños amorosos, ed. Alicia Yllera, Madrid 1983, 258.

47 The edition and the problematic text leads some to believe that "The author neither gave the manuscript to the editor (the dedication to the Duke of Híjar is not hers) nor even had a fully finished text so the book seller tried to arrange it as he could" [my translation], Enrique Suárez Figaredo, "María de Zayas y Sotomayor, Desengaños amorosos" Lemir, 18 (2014), 29; Yllera, who most kindly lent me her copy of the first edition, shares this impression. 
obvious that both works follow the same narrative pattern to produce a commodity. Although critics have pointed out differences between both collections and how the passage of time seems to have produced a strong disenchantment in Zayas, both works not only follow the same narrative formula uniting love tales by the frame story, but they are also set in an academic scenario and with the same characters.

Caro's and Zayas' literary careers prove some women writers managed to put their works in the market in the same way men did, following similar courses of action. This path began participating in local coteries, literary academies, or informal group meetings where connections and recognition could be gained. Poetry was the touchstone, used for the expression of all kinds of topics and necessary for attention and appreciation from the audience. These groups were effective in gaining fame and establishing relationships or simply providing access to persons of high social position and receiving potential patronage, because coteries integrated members of different social classes but were usually sponsored by people of the local elite. ${ }^{48}$ This was the starting point to promote one's literary abilities and eventually seek an economic return for them, either by exploiting opportunities of patronage or by printing for the market. The same handwritten texts that were read and circulated in such coteries could be proposed to patronage or disseminated through the press, as suggested by Pérez de Montalbán mentioning Zayas' novels before publication. ${ }^{49}$ Moreover, literature was often printed after manuscript dissemination and endorsement in these circles. Caro and Zayas were the most successful women writers and prove that gender did not exclude women from the literary market. Their visibility at the time was high enough to make an example for other female writers who realised literary creation could be more than a highbrow and elegant hobby. And, in the same years or sometime after, other woman writers followed suit and published works of the same marketable genres: relaciones, novels and dramas. ${ }^{50}$ In these cases, there is no information on writers' biographies so their professional paths remain unknown, but the genres they chose and the resulting published books suggest they were looking for profit.

48 Jeremy Robbins, Love Poetry of the Literary Academies in the Reign of Philip IV and Charles II, London 1997, 7-46.

49 Juan Pérez de Montalbán, Para todos. Ejemplos morales, humanos y divinos en que se tratan diversas ciencias, materias y facultades repartidos en los siete días de la semana y dirigidos a diferentes personas, Huesca 1633, f. 353v. Pérez de Montalbán says her book is ready for print, but he talks about eight novels and the actual text has ten.

50 See Section III ("Secular literature") and Section Iv ("Women in the Public Sphere") in The Routledge Companion to Early Modern Spanish Women Writers, eds Baranda and Cruz. 


\section{Women Writers in the Literary Market}

In 1638, Ana de Leyva published a eulogy (Panegírico) to Francisco d'Este, Duke of Modena, upon his entrance to Madrid. The Duke was on an official visit to the King of Spain and had a reputation as a generous patron of the arts, something Ana de Leyva stresses in her dedication when she says that a magnificent prince is recognised by his liberality when receiving a small gift. ${ }^{51}$ Angela de Azevedo, possibly of Portuguese origin, might have also written her plays to be staged and to appeal to theatre audiences. The titles of her three works begin with "famous comedy", usually an indication that they had been previously bought by the impresario and performed as such..$^{52}$ It is believed Mariana de Carvajal wrote her collection of novels Navidades de Madrid (Christmastide in Madrid) also to earn money.

Mariana de Carvajal was widowed in 1656 with eight children. In all likelihood, this was her main reason for writing novels, as - although she belonged to a wealthy class, had an allowance and was well connected to people that helped her - it seemed she was in need of money. ${ }^{53}$ Her writing career is unknown; she is not mentioned before or after the publication of her book, although her prose narratives contain many poems that could have been composed for some kind of academy or coterie. Her work has no commendatory poems that might prove her literary connections, but writing appears to be a family pursuit as her son presided over an academy in $1664,{ }^{54}$ and the lack of preliminary texts might be the result of the printing process and not

51 Ana de Leyva, Panigírico en alabanza de la serenissima alteza del gran Francisco de Este duque potentissimo de Modena, Madrid 1638. I shall not refer to Ana de Castro Egas, Eternidad del Rey don Filipe Tercero nuestro señor, el piadoso (Madrid 1629), because according to Peraita her reasons for writing the work may have not been economic only, see Carmen Peraita Huerta, "Apacible brevedad de los renglones, abreviada vida de monarcas: Ana de Castro Egas, Francisco de Quevedo y la escritura del panegírico regio", La Perinola. Revista de Investigación Quevediana, 9 (2005), 151-70; other woman writers who published booklets as a means of developing a literary career in $\mathrm{M}^{\mathrm{a}}$ Carmen Marín Pina, "Pliegos sueltos poéticos femeninos en el camino del verso al libro de poesía. La singularidad de María Nieto", Bulletin Hispanique, 113/1 (2011), 239-67.

52 The works are Comedia famosa. La margarita del Tajo que dio nombre a Santarén, Comedia famosa, Dicha y desdicha del juego y devoción de la Virgen, and Comedia famosa, El muerto disimulado, see Teresa Scott Soufas, Women's Acts. Plays by Women Dramatists of Spain's Golden Age, Lexington 1997, 4-132.

53 See Shifra Armon, Picking Wedlock. Women and the Courtship Novel in Spain, Lanham [etc.] 2002, 43-44 and 173-75

54 On Carvajal's possible participation in academies or coteries, see Moisés Martín Gómez, Mariana de Carvajal: "Industrias y desdenes". Un estudio de las "Navidades de Madrid", Cádiz 2003, 30-34 and 39-40. 
due to the author's isolation. Apart from poetry writing, which was something every young writer did, Mariana de Carvajal seems to have been interested only in commercial genres, novels and plays which were very much in demand as leisure literature. Zayas openly urged readers to buy the book; in her prologue, Carvajal offers the reader "a book with twelve comedies" ("un libro de doce comedias") 55 that she had apparently already composed. She closes the work implying that she is willing to write the second part of the collection. She is not as bold as Zayas in expressing herself, but had the same goal: to try to raise expectations in the reader (prospective buyer), a reason for referring to the most commercial and avidly consumed genres of the time, as editions of plays had increased steadily and collections of novels were published continuously. ${ }^{56}$ The paratexts of Navidades de Madrid suggest that Mariana de Carvajal took all necessary steps to obtain the required printing permissions, even the privilege, which was optional and had primarily an economic purpose. As with Zayas, authors usually obtained it in order to sell the work to a publisher who paid them either with money or book copies, ${ }^{57}$ a negotiation that involved convincing editors of the book's possible success in the market. Once the author sold the original manuscript he or she had no say in the printing process; this is something I argue happened to the Navidades de Madrid, particularly as some mistakes in the text suggest Carvajal never corrected the printed book. ${ }^{58}$ Driven by adverse economic circumstances, Mariana de Carvajal tried her luck in a successful genre in the market and was shrewd enough to get legal permits and sell her work, thus following the same steps as other authors of her time. That could explain why the book publisher, Gregorio Rodríguez, wrote the dedication to Eusebius von Pötting, the Viennese ambassador. He chose a patron, who had arrived in Madrid a few months before and had a reputation as a bookish and generous man. If Carvajal received payment for her literary endeavour, the publisher sold copies and was rewarded by the patron, who says in his

55 "Forgive the shortcomings of a bad cut pen, where you will find more eagerness to serve you with a book with twelve comedies, in which you will know my fondness" ("perdonando los defectos de una tan mal cortada pluma, en la cual hallarás mayores deseos de servirte con un libro de doce comedias, en que conozcas lo afectuoso de mi deseo"), Mariana de Carvajal, Navidades de Madrid y noches entretenidas, ed. Catherine Soriano, Madrid 1993, 5 .

56 Anne Cayuela, Le paratexte au Sicle d'Or. Prose romanesque, livres et lecteurs en Espagne

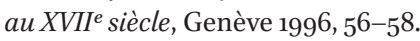

57 Cayuela, Le paratexte, 59-62; and Jaime Moll, "Problemas bibliográficos del libro del Siglo de Oro", Boletín de la Real Academia Española, LIX/216 (1979), 49-107. 
diary: "To him who dedicated a book called Christmastide in Madrid to me, I have given ten doublons". ${ }^{5}$

The emergence of a market for literary products and the resulting partial independence of certain authors was a phenomenon that took over a century to develop since the advent of the printing press. However, writers practiced the rationale of profit long before then, since the beginning of the printing press, as there were large consumption genres that led to business expectations. Chivalry romances were possibly the most popular genre in sixteenthcentury Spain (and Europe) since the Amadis of Gaul success in 1508, soon followed by a number of sequels. ${ }^{60}$ Juana Bernal de Gatos was aware of this when, in 1584, she asked permission for a new edition of Cristalián de España, a chivalry book written by her mother, Beatriz Bernal, and first published in 1545. As Carvajal, Juana declares she is a widow and explains that she wants some income, because she is poor and in need. Nothing is known about the reasons or process leading to the first edition in 1545 as Beatriz Bernal's name is not on it, just "a lady from Valladolid" ("una señora de Valladolid"). Economic imperatives for writing or printing the book are difficult to assess. The printing license was requested and granted in 1537 to a "Mossior of Anthoven" and the privilege belonged to the editor, Christóbal Pelegrin: two men who could have been essential intermediaries for Beatriz Bernal to obtain legal permits. Nevertheless there were too many people involved in Bernal's project for it not to have economic interests, particularly as, in 1532 in Valladolid, three chivalry books were published along with two more in 1545 , meaning it was a popular genre. ${ }^{61}$ Juana Bernal clearly states economic motivation as reason to publish her mother's work, but it is surprising that the archival documents Gagliardi recovered ${ }^{62}$ show she was affluent. Official requests were often based on such topical reasons, so it is not odd Juana spoke of herself as a poor widow if that could ease the procedure. Whether profitable or not, either for money or for other reasons, her petition is evidence of the fact that society accepted, even in the sixteenth century and in a limited literary book market, women's initiatives to obtain benefits from printing a work. They

59 "A uno que me dedicó un libro llamado Navidades de Madrid he dado 10 doblones" Armon, Picking Wedlock, 175 .

6o M. ${ }^{a}$ Carmen Marín Pina, "Los libros de caballerías castellanos", in "Amadís de Gaula", 1508: quinientos años de libros de caballerías, ed. José Manuel Lucía Megías, Madrid 2008, 165-9o.

61 Donatella Gagliardi, Urdiendo ficciones. Beatriz Bernal, autora de caballerías en la España del siglo XVI, Zaragoza 2010, 133-39.

62 Ibid., 79-103. 
were perfectly aware of this possibility, which could stimulate their interest in writing. ${ }^{63}$

\section{Professional Wise Maidens}

Monetary gains hint at a market society in which profit is expressed in clearly quantifiable terms, but there were other ways to benefit from knowledge or writing abilities. Although he made money, Lope de Vega always longed for a permanent job as chronicler or secretary, which he never got. More generally, writers sought means to be rewarded with favours or gifts within the patronage system of the time. Women were aware of these alternative forms of profit, too, and wrote in order to obtain them. For example, Luisa Sigea held well-paid positions in court because of her knowledge of classical languages. In her youth, Bernarda Ferreira de Lacerda dedicated a poem to King Philip III, in which certain Portuguese family lineages are highlighted with a view to promoting them. Also, in convents, many nuns resorted to writing to help solve economic problems, to meet certain domestic needs, or to sustain patronage networks. These women used literature not as simple amusement or a free expression of their creativity, but with a utilitarian purpose resulting from carefully thought-out decisions.

Some women writers, including Ana Caro and Ana de Leyva, sought aristocratic patronage, but their reward was some form of payment for a piece of work. Striving for a position or a job based on their literary talents was out of the question: women could not be secretaries or chroniclers. Ladies of the Queen's chamber had their own institutional space and received a salary for their work, among other forms of compensation. In a sense, it was one of the few professional opportunities for aristocratic and elite women. ${ }^{64}$ Because of the restricted and exclusive character of this group, it was especially difficult to get access unless you were a member of the aristocracy; however, some women attained it because of their knowledge.

63 Being a poor widow cannot be discarded as the major reason for getting permission, as widows were a particularly disadvantaged group that the law and society as a whole were inclined to protect. It seems that women were particularly attracted by the chivalric genre and although Beatriz Bernal is the only known author, other works are said to have been composed by women in a covert way, for example the Palmerín de Olivia. In Italy and

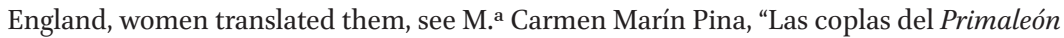
y otros versos laudatorios en los libros de caballerías", in Actes del X Congrés Internacional de l'Associació Hispànica de Literatura Medieval (Alacant, 16-20 setembre de 2003), Alacant 2005, 2, 1057-66, and Gagliardi, Urdiendo ficciones, 105-36.

64 M. Victoria López-Cordón, "Entre damas anda el juego: las camareras mayores de Palacio en la edad moderna”, Cuadernos de Historia Moderna, 123 (2003), 126. 
Luisa Sigea (c. 1522-1560) and her sister, Angela, were daughters of a humanist professor who taught Spanish and Portuguese to aristocratic families, and this was possibly the reason why he decided to educate his daughters following the model of the 'new aristocrat' ladies who learnt classical languages and culture. ${ }^{65}$ The girls mastered Greek, Latin, grammar, rhetoric and music, and, using their connections, they entered the Portuguese court to serve Queen Catherine and Infanta Maria of Portugal. According to the Livros de moradia or Queen Catherine ledgers, in 1543, 1550, and 1551, Luisa received as latina (Latin teacher or secretary) 16 ,ooo reis annually. The amount measures her importance in comparison to other educated ladies, for example, Joana Vaz, who taught Latin and received 10,000 reis in 1550. While living in the Portuguese court, Sigea composed a Latin poem and a dialogue dedicated to the Infanta, but was not paid for them. Her profit came instead from her increased influence inside and outside of court and her promotion as a cultivated intellectual, which bolstered her professional value. European fifteenth- and sixteenth-century professional humanists began their careers teaching and their prospects increased as their prestige grew, allowing them sometimes to become court scholars. Luisa Sigea could not become a college professor, but because of her upbringing and her father's connections to the Portuguese court (albeit not from a great lineage), she was allowed to enter Queen Catherine's chamber around 1540. She proceeded, like other humanists, to self-fashion a 'wise woman' image through letters to important people, including the Pope. Although, in 1540, she sent him some poems in Latin, Sigea is remembered in lists of European famous women for having sent a letter to Pope Paul III in five languages: Latin, Greek, Arabic, Hebrew, and Chaldean. The now lost text is always mentioned as a letter, but writing a letter in five languages can only be considered an exercise in scholarly exhibition to demonstrate a huge breadth of knowledge. Such a text was presumably made for promotional reasons as, from Rome's adequate circles and the summit of Catholic power, news could tour Europe and return to the Portuguese court in the form of admiration. In fact John Vaseo (1552), Francisco de Pisa (1605), Andreas Schott (1608) and Pietro Paolo Ribera (1609) among others, mentioned this extraordinary woman in their works and her letter to the Pope is the most commented upon feat. ${ }^{66}$ Unlike most of the Infanta's chamber ladies, Luisa Sigea did not descend from a great lineage and strengthened her court position by writing in the language of the cultural elite. Writing in

65 Nieves Baranda, “Luisa Sigea, la brillante excepción femenina”, in Melchor Cano y Luisa Sigea. Dos figuras del Renacimiento español, ed. Miguel Ángel Pérez Priego, Tarancón 2008, 129-51.

66 Information on these and other citations can be retrieved in BIESES data base by searching "Sigea menciones coetaneas". 
Latin, she flattered Infanta Maria in dedications (Sintra and Coloquium), and her letters remind everyone from time to time that she is a remarkable woman. In the various scales of prestige operating in court, Sigea places herself at the summit where the fields of woman and classical learning meet, but as symbolic positions are very unstable their bases must be constantly renewed. Latin letters addressed to powerful and famous men of the time served to preserve and consolidate her personal and professional position. ${ }^{67}$

Luisa Sigea married a Spanish court steward and went to live in Castile. Between 1556 and 1558, the couple was in the service of Emperor Charles v's sisters, but when the Empress Dona Maria died they had to find new positions. Sigea died in 156o, but in those two years, she could not return to work in the court, as she had wanted, although she addressed many influential people and kept in touch with courtly literary circles. ${ }^{68}$ Her frustration is a symptom of a new reality: from this point onwards, Spanish 'wise women', those who were highly educated, could not develop their intellectual skills except from the inside of convents. Juliana Morell's (1594-1653) excellent education in Latin was employed in commenting on religious works while living in the convent of Sainte Praxède of Avignon (France). The well-known writer sor Juana Inés de la Cruz (1651-1695), after a short period in the vice-royal court in Mexico when she was 13 and 14, wrote from a Hieronymite monastery in the city. ${ }^{69}$

\section{The Quiet Writing Jobs of Nuns}

Nun writers are most commonly associated with autobiographical writing and accounts of religious experiences, such as Teresa of Avila. However, leaving aside liturgical and meditative texts used in monasteries, the prevailing literary genre was poetry. ${ }^{70}$ Usually sung, it was used in many ways: in everyday and special

67 Only four Spanish and 19 Latin letters remain, see Léon Bourdon and Odette Sauvage, "Recherches sur Luisa Sigea", Bulletin des Études Portugaises, XXXI (1970), 33-176; and M.R. Prieto Corbalán, Luisa Sigea, epistolario latino, Madrid 2007.

68 Nieves Baranda, "Feminae poeticae. Una generación de mujeres poetas de mediados del siglo XV", in Grandes y pequeños de la literatura medieval y renacentista, ed. Emilio Blanco, Salamanca 2016, 17-53.

69 See Theresa M. Lamy, Juliana Morell: Child Prodigy, Religious Reformer, Spiritual Writer, New York University, Graduate School of Arts and Science, 1992 (PhD. Thesis), and one of the latest sor Juana's biographies, although there are more, Alejandro Soriano Vallès, Sor Juana Inés de la Cruz, Doncella del Verbo, México 2010.

70 Nieves Baranda, "Producción y consumo poéticos en los conventos femeninos", Bulletin Hispanique, CXv/1 (2013), 165-84. 


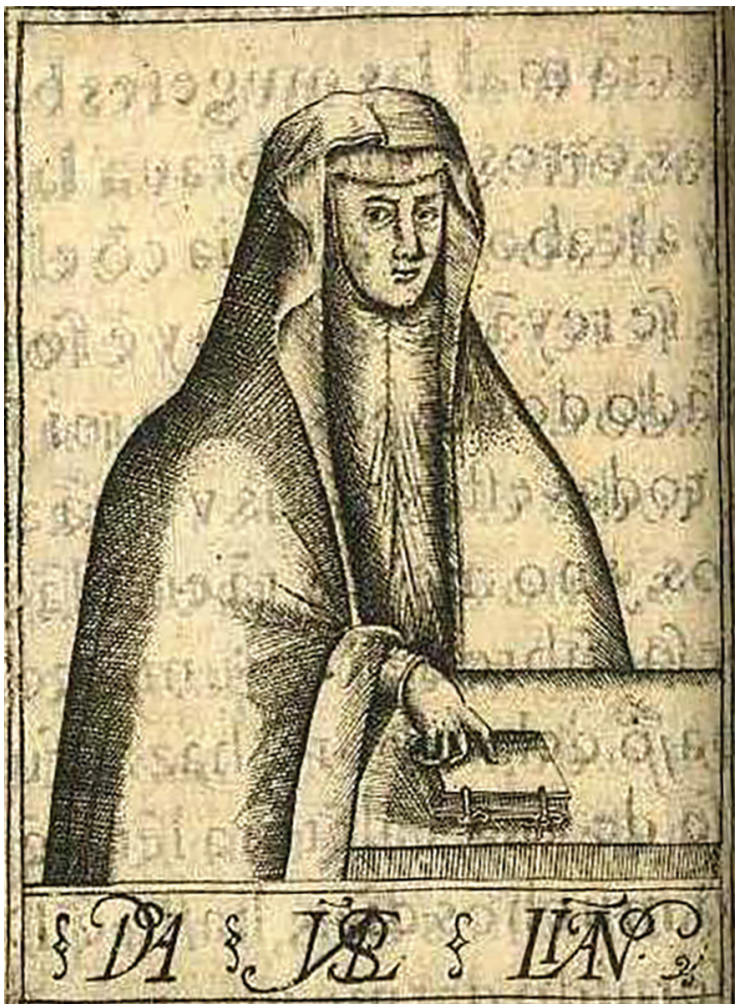

FIGURE 3.1 Isabel de Liaño, Vida de santa Catalina de Siena, Valladolid, 16o4, engraving in page $9 v$. ordered by the woman writer and representing her dressed as a widow making a typical authorial sign touching the book with her finger. COURTESY OF THE HISPANIC SOCIETY OF AMERICA, NEW YORK.

occasions or ceremonies that had to be solemnised with music, mostly associated with religious lyrics in Spanish. Used to sing popular traditional songs a lo divino (changing the original profane words to give them a religious content), many nuns easily composed small poems for their private use as prayers or to be shared with the community. However, formal occasions needed quality verses to be sung to music and had to be composed by experts. ${ }^{71}$ It can be concluded that seventeenth-century monasteries contributed to a poetry trade to meet their needs, although there is scarce documentary evidence of this.

71 Music's importance in convents and its economic side will not be commented on in this chapter, although it was closely related to poetry, see Colleen Baade, "'Hired Nun Musicians in Early Modern Castile" in Musical Voices of Early Modern Women: Many-Headed Melodies, ed. Thomasin LaMay, Aldershot/Burlington 2005, 287-310. 
Sor Marcela de San Félix (1605-1687), a Trinitarian nun and talented poet, presents in one of her short plays a poor starving student wondering how to compose a loa (short dramatic preliminary piece), because some nuns had promised to give him food for the work. ${ }^{72}$ The play proves convents turned to local poets, either well known or simply amateurs, when poems for special occasions were needed. Professional and famous writers, such as Vicente Sánchez or León Marchante, include in their works poems composed for celebrations in feminine monasteries, and there are a few plays written by male authors for festivities in convents. ${ }^{73}$ Sor Marcela's play provides evidence that some proficient nuns were able to meet convent literary needs. She did not write her works to be sold, but her compositions contributed to the community's economy because it did not buy texts. The register of deceased sisters (necrologio) of the Anunciada monastery in Villafranca del Bierzo (León) says of Mother Bernardina de Jesús: "While a novice our mother vicaress taught her to paint registers and other nice things. When vicaress herself, she painted and decorated the cloisters, made drawings for and prepared church ornament embroideries, and thereby the Community saved many ducats". ${ }^{74}$ The key concept is saving. Indeed, nun writers were profitable for their communities and contributed to their revenues not by selling their texts, but by avoiding expenses. This might be the reason why priests who disapproved of women's writing did not complain of those who were even forced to do it on behalf of their own community. For instance the Seville nun, Valentina Pinelo (?- 1629) complains:

All the year I was busy with the order festivities, making some poems that will soon be published ... But that was such a tiring exercise that I have run out of strength and if I had not abandoned that other book I would have

72 Marcela de San Félix, Obra completa. Coloquios espirituales, loas y otros poemas, eds Electa Arenal and Georgina Sabat de Rivers, Barcelona 1988, 361-68

73 On Vicente Sánchez, Lira poética, 1688, and León Marchante (d. 1688), see Baranda, "Producción y consumo", 270-71. The playwright has been studied by Carmen Alarcón Román, "El cumpleaños de la abadesa: una loa de Alonso Martín Brahones en el Convento de Santa Inés de Sevilla (1671)", Teatro. Revista de estudios teatrales, 19 (2003), 107-34, other examples in Antonio Cruz Casado, "Villancicos barrocos andaluces para diversas fiestas del convento de Santa Clara de Montilla (1684-1737)", in El franciscanismo en Andalucía: conferencias del I Curso de verano sobre el franciscanismo en Andalucía (Priego de Córdoba, 7 a 12 de agosto de 1995), ed. Manuel Peláez del Rosal, Córdoba 1997, 325-46.

74 "En el noviciado la enseñó nuestra madre vicaria a pintar registros y otras curiosidades. Siendo vicaria, pintó y decoró los claustros, dibujaba y preparaba el bordado de ornamentos para la iglesia, y con ello ahorró a la Comunidad muchos ducados" [emphasis added, $\mathrm{NB}], \mathrm{M}^{\mathrm{a}}$ del Carmen Arias, La ilustre fundadora de "La Anunciada": María de la Trinidad Toledo y Mendoza (1581-1637), una historia fascinante, Villafranca del Bierzo 2009, 172. 
never finished this one, and here I recovered the health I lost there: the poem book has been the toil and here the recreation..$^{75}$

Nearly a hundred years later in introducing one of her poems, Francisca de Santa Teresa (1654-1709) describes painful circumstances too:

Having funded lady Fabiana Soriana a chaplaincy for her son sir Juan Antonio de los Reyes, sor María de Santa Gertrudis' brother, it was founded in the holy Christ of piety altar, and the day he took up the position ... I was ordered to write in spite of my right hand being hurt. ${ }^{76}$

In her study of convent poetry in Italy, Graziosi wonders why nuns composed poems and, among other reasons, she notes that sometimes they did it because of fame, the small local fame that could draw alms to the convent. ${ }^{77}$ Monasteries were heavily dependent on charity, which came mainly from the surrounding people in the city, so their economic situation deteriorated during the seventeenth century, following the country's living conditions. When there were several monasteries in the same city, competition for these resources was hard, and being remembered and taken into account could be important. Sister Manuela de la Santísima Trinidad's (1622-1696) convent chronicle devoted a chapter to the poverty they lived in, because alms had fallen sharply, so Mercedes Marcos assumes that the reason to publish it could be reminding Salamanca's people that Franciscan nuns were very holy, privileged intercessors before God and worthy of their alms. ${ }^{78}$

75 "me ocupaba todo el año en las fiestas de la orden, haciendo algunas letras que saldrán ahora ... Pero aquel era un ejercicio tan cansado que me han faltado las fuerzas y si no dexara esotro libro nunca acabara este y aquí cobré la salud que allí perdí: en el cancionero ha sido el trabajo y aquí el descanso", Libro de las a labanças y excelencias de la gloriosa Santa Anna, Sevilla 16o1, prologue.

76 "Haviendo fundado doña Fabiana Soriana una Capellanía en su hijo D. Juan Antonio de los Reyes, hermano de Sor María de Santa Gertrudis, fundósse en el Altar del Santíssimo Christo de la Piedad, y el día que tomó la possessión ... me mandaron escribir, teniendo mala la mano derecha", Francisca de Santa Teresa, Poesías de la Madre sor Francisca de Santa Teresa, religiosa trinitaria descalza en la Villa de Madrid, manuscript, 18th century, ff. 217V-219r, apud Isabel Barbeito, Escritoras madrileñas del siglo XVII (Estudio bibliográficocrítico), Universidad Complutense, PhD. Thesis, 1986, 270 [in Bieses website].

77 Elisabetta Graziosi, "Arcipelago somerso. Le rime delle monache tra obbedienza e trasgressione" in I monasteri femminili come centri di cultura fra Rinascimento e Barocco, eds Gianna Pomata and Gabriella Zarri, Roma 2005, 162.

78 Fundación del Convento de la Puríssima Concepción de Franciscas Descalzas de la ciudad de Salamanca, Salamanca 1696, see María Fernanda Prada Camín and Mercedes Marcos Sánchez, Historia, vida y palabra del Monasterio de la Purísima Concepción (Franciscas 
Besides alms, monasteries depended on and cared for their patrons' generosity. Monastery founders and their descendants had a special relationship with the community to which they contributed financially in exchange for continual prayers or other privileges (burial sites, priority for family novices and so on). As with relaciones to flatter patrons, nuns could write for utilitarian aims. Sister Francisca de Santa Teresa's poetry is useful to demonstrate how writing could be productive when some poems are devoted to wish 'happy birthday' to relevant people for the convent:

These two poems to the most glorious martyrs saint Justo and saint Pastor and others that may be found in this book I made at different times commissioned by Mr. Doctor Don Gabriel Sanz, his own priest and His Eminence's convents visitor. Romance for his day.

“To Miss María Rosa de la Cerda Téllez Xirón's two-year birthday, Don Ioseph Manrrique de la Cerda's and Dona Manuela Téllez Xirón's daughter, Marquises of La Laguna, the female author congratulates her with these verses".79

These poems were written to awaken patrons' generosity, even if the nun's work did not seek personal gain, but the community's benefit. It is surprising how nuns' writings refer very often to suffering real poverty and how many documents are related to the economic management of convent property compared to the lack of specific references to the commodification of their artistic skills. Baade, who has studied music extensively, stresses that it is difficult 'to know the extent to which nuns' music-making was motivated by zeal for appropriate worship versus the expectation of possible benefits (prestige? continued financial support from patrons?) that may have been associated with public performances". ${ }^{80}$ And indeed leaves the question unanswered for

Descalzas) de Salamanca, Salamanca, 2001, 161. I thank Mercedes Marcos who called my attention on it. On poverty in Spanish convents see Ángela Atienza, "Lo reglado y lo desarreglado en la vida cotidiana de los conventos femeninos en la España Moderna", in $L a$ vida cotidiana en el mundo hispánico (siglos XVI-XVIII), ed. M. Peña, Madrid 2012, 445-65.

"Estas dos letras a los gloriossíssimos mártires San Justo y Pastor y las que se hallaren en este Libro las hiçe en diferentes ocasiones de mandato del señor Doctor Don Gabriel Sanz, su cura propio y visitador de los conbentos sujetos a su Eminencia. Romance para su día", "Al cumplimiento de los dos años de la Sra. $\mathrm{D}^{\mathrm{a}}$ María Rosa de la Çerda Téllez Xirón, hija de los Excellentíssimos señores Don Ioseph Manrrique de la Cerda y de Da Manuela Téllez Xirón, Marqueses de la Laguna, se los da la autora en estas coplas". The Marquisses were the monastery patrons, see Baranda, "Producción y consumo", 173.

8o Coleen Baade, "Music and Misgiving: Attitudes Towards Nuns' Music in Early Modern Spain", in Cordula van Wyhe, Female Monasticism in Early Modern Europe. An Interdisciplinary View, Aldershot 2008, 89. 
lack of data in the sources, as it happens with literature. It is very likely that following elite or court social patterns, literary works, like music, were considered a prestigious sign, an ornamental activity that would degrade when exchanged or produced for money because that would turn it into a commodity. Nuns who had a dowry waive for their artistic or musical abilities, although formally part of the convent elite group, were actually regarded as having an inferior status, as their work had to pay for their living and was subject to commodification. ${ }^{81}$ While in literary circles these concepts changed under the pressure of the publishing market, nuns did not change, so even if the logic of profit was understood and accepted, voicing it was inappropriate.

Literary history tends to present women's writing as an individual act, the result of a creative impulse, a need for expression that manages to overcome social barriers or as a prestigious form of entertainment for the elite. Considering economic aspects in early modern Spain reveals that, despite women's comparative weakness in the literary field, women writers paid to profit no less attention than men. Their works had often an economic or utilitarian purpose and adopted the same tactics employed by men to get the benefit they wanted. Some of them succeeded in doing so.

\section{Bibliography}

\section{Primary References}

Caro, Ana. 1993. El conde Partinuplés (ed. Lola Luna). Kassel: Reichenberger.

Caro, Ana. 1993. Valor, agravio y mujer (ed. Lola Luna). Madrid: Castalia.

Carvajal, Mariana de. 1993. Navidades de Madrid y noches entretenidas (ed. Catherine Soriano). Madrid: Comunidad de Madrid.

Castillo Solórzano, Alonso de. 1972. La garduña de Sevilla y anzuelo de las bolsas (ed. Federico Ruiz Morcuende). Madrid: Espasa-Calpe.

Castro Egas, Ana de. 1629. Eternidad del Rey don Filipe Tercero nuestro señor, el piadoso (Madrid: Viuda de Alonso Martín).

81 "Their productive service activity lowered their prestige in community, however, by likening them to the lay sisters who performed manual chores in the convent. The former servant, Maria de la Santisima Trinidad, could not rise in the status structure because her productive artistic acts continually reminded of her service capacity and Estefania de la Encarnacion's prestige also was diminished by her productive artistic acts in lieu of a dowry", Mindy Nancarrow Taggard, "Art and Alienation in Early Modern Spanish Convents", South Atlantic Review, 65 (2000), 27. Donald Gilbert-Santamaría, Writers on the Market, 24, underlines how the ruling elite in Spain resisted to mercantilist activity out of cultural barriers to the promotion of market ideology beyond the traditional artisan classes. 
Leyva, Ana de. 1638. Panigírico en alabanza de la serenissima alteza del gran Francisco de Este duque potentissimo de Modena. Madrid: Imprenta del Reino.

Marcela de San Félix. 1988. Obra completa. Coloquios espirituales, loas y otros poemas (eds Electa Arenal and Georgina Sabat de Rivers). Barcelona: PPU.

Pérez de Montalbán, Juan. 1633. Para todos. Ejemplos morales, humanos y divinos en que se tratan diversas ciencias, materias y facultades repartidos en los siete días de la semanay dirigidos a diferentes personas. Huesca: Pedro Blusón, a costa de Pedro Escuer.

Pinelo, Valentina. 1601. Libro de las alabanças y excelencias de la gloriosa Santa Anna. Sevilla: Clemente Hidalgo.

Vega Carpio, Félix Lope. 1914. Arte nuevo de hacer comedias [16o9] (tr. William T. Brewster). New York: Dramatic Museum of Columbia University.

Vega Carpio, Félix Lope de. 2002. Laurel de Apolo (ed. Christian Giaffreda). Firenze: Alinea Editrice s.r.l.

Vélez de Guevara, Luis. 1988. El diablo cojuelo [1641] (eds Ángel R. Fernández and Ignacio Arellano). Madrid: Castalia.

Zayas, María de. 199o. The Enchantments of Love: Amorous and Exemplary Novels (tr. H. Patsy Boyer). Berkeley: University of California Press.

\section{Secondary References}

Alarcón Román, Carmen. 2003. 'El cumpleaños de la abadesa: una loa de Alonso Martín Brahones en el Convento de Santa Inés de Sevilla (1671)' in Teatro. Revista de estudios teatrales 19: 107-34.

Arias, $\mathrm{M}^{\mathrm{a}}$ del Carmen. 2009. La ilustre fundadora de "La Anunciada": María de la Trinidad Toledo y Mendoza (1581-1631), una historia fascinante. Villafranca del Bierzo: Instituto de Estudios Bercianos.

Armon, Shifra. 2002. Picking Wedlock. Women and the Courtship Novel in Spain. Lanham [etc.]: Rowman \& Littlefield Publishers.

Atienza, Ángela. 2012. 'Lo reglado y lo desarreglado en la vida cotidiana de los conventos femeninos en la España Moderna' in M. Peña (ed.), La vida cotidiana en el mundo hispánico (siglos XVI-XVIII). Madrid: Abada editores: $445^{-65}$.

Baade, Coleen. 2008. 'Music and Misgiving: Attitudes Towards Nuns' Music in Early Modern Spain' in Cordula van Wyhe (ed.), Female Monasticism in Early Modern Europe. An Interdisciplinary View. Aldershot: Ashgate: 81-96.

Baade, Colleen. 2005. 'Hired Nun Musicians in Early Modern Castile' in Thomasin LaMay (ed.), Musical Voices of Early Modern Women: Many-Headed Melodies. Aldershot and Burlington: Ashgate: $287-310$.

Baranda, Nieves. 2008. 'Luisa Sigea, la brillante excepción femenina' in Miguel Ángel Pérez Priego (ed.), Melchor Cano y Luisa Sigea. Dos figuras del Renacimiento español. Tarancón: Ayuntamiento de Tarancón and Centro Asociado de la UNED de Cuenca: $129-51$. 
Baranda, Nieves. 2011. 'Women's Reading Habits: Book Dedications to Female Patrons in Early Modern Spain' in Anne J. Cruz and Rosilie Hernández (eds), Women's Literacy in Early Modern Spain and the New World. Hampshire and Burlington: Ashgate: $19-39$.

Baranda, Nieves. 2013. 'Producción y consumo poéticos en los conventos femeninos' in Bulletin Hispanique, $\operatorname{cxv}(1): 165^{-84}$.

Baranda, Nieves and Anne J. Cruz (eds). 2017. The Routledge Companion to Early Modern Spanish Women Writers, London/New York: Routledge. [Spanish trans. Escritoras españolas de la edad Moderna. Historia y guía de investigación. Madrid: UNED, 2018.]

Barbeito, Isabel. 1986. Escritoras madrileñas del siglo XVII (Estudio bibliográfico-crítico). PhD. Thesis. Universidad Complutense. [in Bieses website].

Bourdieu, Pierre. 1995. Las reglas del arte. Génesis y estructura del campo literario. Barcelona: Anagrama.

Bourdon, Léon and Odette Sauvage. 1970. 'Recherches sur Luisa Sigea' in Bulletin des Études Portugaises XXXI: 33-176.

Cañadas, Iván. 2005. Public theater in Golden Age Madrid and Tudor-Stuart London: Class, Gender and Festive Community. Aldershot/Burlington: Ashgate.

Cañas Murillo, Jesús. 200o. 'Lope de Vega, Alba de Tormes y la formación de la comedia' in Anuario de Lope de Vega vi: 75-92.

Carrión Arregui, Ignacio M. 20oo. 'El trabajo en una manufactura real del siglo XVII: los armeros de la Armería de Tolosa' in Vasconia 30: 73-82.

Cayuela, Anne. 1996. Le paratexte au Sicle d'Or. Prose romanesque, livres et lecteurs en Espagne au XVII e siècle. Genève: Droz.

Colomer, José Luis. 2005. 'El conde de la Roca y el marqués Virgilio Malvezzi. Dos diplomáticos panegiristas del Conde Duque de Olivares' in Christophe Couderec and Benoit Pellistrandi (eds), Por discreto y por amigo. Mélanges offerts à Jean Canavaggio. Madrid: Casa de Velázquez: 513-34.

Cruz Casado, Antonio. 1997. 'Villancicos barrocos andaluces para diversas fiestas del convento de Santa Clara de Montilla (1684-1737)' in Manuel Peláez del Rosal (ed.), El franciscanismo en Andalucía: conferencias del I Curso de verano sobre el franciscanismo en Andalucía (Priego de Córdoba, 7 a 12 de agosto de 1995). Córdoba: Caja de Ahorros y Monte de Piedad de Córdoba: 325-46.

Elliot, John H. 1986. The Count-Duke of Olivares. The Statesman in an Age of Decline. New Haven: Yale University Press.

Enciso Alonso-Muñumer, Isabel. 2008. 'Nobleza y mecenazgo en la época de Cervantes', in Anales Cervantinos, 40: 47-61.

Ferrer Valls, Teresa. 2003. 'La fiesta en el Siglo de Oro: en los márgenes de la ilusión teatral' in Teatro y fiesta del Siglo de Oro en tierras europeas de los Austrias. Madrid: SEACEX: $27-37$. 
Ferrer, Teresa. 2009. 'La mujer sobre el tablado en el siglo XVII: de actriz a autora' in Damas en el tablado. Actas de las XXXI Jornadas Internacionales de teatro clásico de Almagro (1-3 de julio de 20o8). Almagro: Universidad de Castilla-La Mancha: 83-10o. Gagliardi, Donatella. 2010. Urdiendo ficciones. Beatriz Bernal, autora de caballerías en la España del siglo XVI. Zaragoza: Prensas Universitarias de Zaragoza.

Gamboa, Yolanda. 2011. 'María de Zayas, or Memory Chains and the Education of a Learned Woman', in Anne J. Cruz and Rosilie Hernández (eds), Women's Literacy in Early Modern Spain and the New World. Hampshire and Burlington: Ashgate: 209-24.

García Santo-Tomás, Enrique. 200o. 'Lope, ventrílocuo de Lope: Capital social, capital cultural y estrategia literaria en las Rimas de Tome de Burguillos (1634)' in Bulletin of Spanish Studies, 77(4): 287-303.

Gilbert-Santamaría, Donald. 2005. Writers on the Market. Consuming Literature in Early Seventeenth-Century Spain. Lewisburg: Bucknell University Press.

Gómez García, Pedro. 1999. 'Hipótesis sobre la estructura y función de las fiestas' in La fiesta, la ceremonia, el rito. Granada: Universidad de Granada: 51-62.

Graziosi, Elisabetta. 2005. "Arcipelago sommerso. Le rime delle monache tra obbedienza e trasgressione" in Gianna Pomata and Gabriella Zarri (eds), I monasteri femminili come centri di cultura fra Rinascimento e Barocco. Roma: Edizioni di Storia e Letteratura: $145^{-73}$.

Gudiol, José. 1973. Velázquez, 1599-166o: historia de su vida, catálogo de su obra, estudio de la evolución de su técnica. Barcelona: Polígrafa.

Gutiérrez, Carlos M. 2005. La espada, el rayo y la pluma. Quevedo y los campos literario y de poder. West Lafayette, Ind.: Purdue University Press.

Huerta Calvo, Javier (ed.). 2003. Historia del teatro español. Madrid: Gredos.

Kaplisch-Zuber, Christine. 1985. 'Rituals publics et pouvoir d'état' in Culture et ideologie dans la genese de l'état moderne. Rome: École française de Rome: 136-53.

Lamy, Theresa M. 1992. Juliana Morell: Child Prodigy, Religious Reformer, Spiritual Writer. PhD. Thesis. New York University.

López Estrada, Francisco. 1978. 'La relación de las fiestas por los mártires del Japón, de doña Ana Caro de Mallén (Sevilla), 1628' in Libro-homenaje a Antonio Pérez Gómez. Cieza: La fonte que mana e corre: II 5 1-69.

López Estrada, Francisco. 1983. 'Costumbres sevillanas: el poema sobre la Fiesta y Octava celebradas con motivo de los sucesos de Flandes en la Iglesia de San Miguel (1635), por Ana Caro de Mallén' in Archivo Hispalense LXVI(203): 109-50.

López Estrada, Francisco. 1983. 'La frontera allende el mar: el romance por la victoria de Tetuán (1633) de Ana Caro de Mallén’ in Dámaso Alonso (ed.), Homenaje a José Manuel Blecua, ofrecido por sus discípulos, colegas y amigos. Madrid: Gredos: 337-46. López-Cordón, M. Victoria. 2003. 'Entre damas anda el juego: las camareras mayores de Palacio en la edad moderna' in Cuadernos de Historia Moderna, 123: 123-152. 
Luna, Lola. 1992. Ana Caro, una escritora profesional del Siglo de Oro. Viday obra. Ph.D. Thesis. Universidad de Sevilla.

Maravall, José Antonio. 1981. La cultura del barroco. Análisis de una estructura histórica. Barcelona: Ariel.

Marín Pina, M. ${ }^{a}$ Carmen. 2005. 'Las coplas del Primaleón y otros versos laudatorios en los libros de caballerías' in Actes del X Congrés Internacional de l'Associació Hispànica de Literatura Medieval (Alacant, 16-20 setembre de 2003). Alacant: Institut Interuniversitari de Filologia Valenciana: 2, 1057-66.

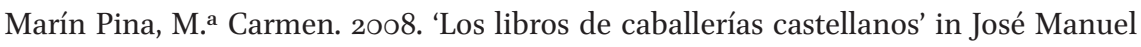
Lucía Megías (ed.), “Amadís de Gaula”, 1508: quinientos años de libros de caballerías. Madrid: Biblioteca Nacional de España/Sociedad Española de Conmemoraciones Culturales: $165^{-9}$ o.

Marín Pina, Ma Carmen. 2011. 'Pliegos sueltos poéticos femeninos en el camino del verso al libro de poesía. La singularidad de María Nieto' in Bulletin Hispanique $113(1): 239-67$.

Marín Pina, Ma Carmen. 2017. 'Public Poetry' in Baranda and Cruz (2017): 205-18.

Maroto Camino, Mercedes. 1999. 'Maria de Zayas and Ana Caro: The Space of Woman's Solidarity in the Spanish Golden Age' in Hispanic Review 67: 1-16.

Martín Gómez, Moisés. 2003. Mariana de Carvajal: "Industrias y desdenes". Un estudio de las "Navidades de Madrid". Cádiz: Universidad de Cádiz.

Martos Pérez, María Dolores. 2017. 'De musas a poetas: escritoras y enunciación canonizadora en la obra de Lope de Vega', Arte nuevo 4: 787-847.

Moll, Jaime. 1974. 'Tercera parte de las comedias de Lope de Vega Carpio y otros autores, falsificación sevillana' in Revista de Archivos, Bibliotecas y Museos 77: 619-26.

Moll, Jaime. 1979. 'Problemas bibliográficos del libro del Siglo de Oro' in Boletín de la Real Academia Española LIX(216): 49-107.

Nancarrow Taggard, Mindy. 2000. 'Art and Alienation in Early Modern Spanish Convents' in South Atlantic Review 65: 27.

Noble Wood, O.J. Roe, J. Lawrence (eds). 2011. Poder y saber. Bibliotecas y bibliofilia en la época del conde-duque de Olivares, Madrid: Centro de Estudios Europa Hispánica.

Osuna, Inmaculada. 2017. 'Literary Academies and Poetic Tournaments' in Baranda and Cruz (2017): 153-67.

Peraita Huerta, Carmen. 2005. 'Apacible brevedad de los renglones, abreviada vida de monarcas: Ana de Castro Egas, Francisco de Quevedo y la escritura del panegírico regio' in La Perinola. Revista de Investigación Quevediana 9: 151-70.

Pérez Pastor, Cristóbal. 1910. Noticias y documentos relativos a la historia y literatura españolas, Madrid: RAE.

Prada Camín, María Fernanda and Marcos Sánchez, Mercedes. 20o1. Historia, vida y palabra del Monasterio de la Purísima Concepción (Franciscas Descalzas) de Salamanca. Salamanca: Publicaciones Universidad Pontificia. 
Prieto Corbalán, M.R. 2007. Luisa Sigea, epistolario latino. Madrid: Akal.

Profetti, Ma Grazia. 1999. 'Poder y estrategias editoriales de Lope de Vega', in M.G. Profeti y A. Redondo (eds), Représentation, écriture et povoir en Espagne a l'epoque de Philippe III (1598-1621). Firenze: Alinea: 87-105.

Robbins, Jeremy. 1997. Love Poetry of the Literary Academies in the Reign of Philip IV and Charles II. London: Tamesis.

Sánchez Arjona, José. 1898. Noticias referentes a los anales del teatro en Sevilla, desde Lope de Rueda hasta fines del siglo XVII. Sevilla: Imp. de E. Rasco.

Scott Soufas, Teresa. 1997. Women's Acts. Plays by Women Dramatists of Spain's Golden Age. Lexington: The University Press of Kentucky.

Soriano Vallès, Alejandro. 2010. Sor Juana Inés de la Cruz, Doncella del Verbo. México: Garabatos.

Suárez Figaredo, Enrique. 2014. 'María de Zayas y Sotomayor, Desengaños amorosos' in Lemir, 18: 353-572.

Villegas, Esther. 2009. 'Transatlantic interactions: seventeenth century women authors and Literary self -consciousness' in Claire Taylor (ed.), Identity, Nation, Discourse. Latin American Women Writers and Writers. Newcastle upon Tayne: Cambridge Scholars: 104-21.

Walker, Kim. 1996. Women Writers of the English Renaissance. New York: Twayne Publishers.

Wright, Elizabeth R. 2001. Pilgrimage to Patronage. Lope de Vega and the Court of Philip III, 1598-1621. Lewisburg: Bucknell University Press.

Zuese, Alicia R. 2011. 'Ana Caro and the Literary Academies of Seventeenth-Century Spain' in Anne J. Cruz and Rosilie Hernández (eds), Women's Literacy in Early Modern Spain and the New World. Hampshire and Burlington: Ashgate: 191-208. 